\title{
An Ethical Climate Is a Duty of Care
}

\author{
Anona Armstrong and Ronald Francis \\ Victoria University, Australia
}

\begin{abstract}
The current emergence, once again, of corporate collapses due in no small way to unethical behaviour raises questions about the duties and responsibilities of boards of major organisations for building an ethical organisation. This paper argues that the legal duty of care to employees extends to creating an ethical work environment. It describes different types of ethical climates, how they are recognised and the consequences of their impact on the behaviours of their members. It illustrates this with some of the findings from our research into measuring ethics and ethical decision making. In conclusion, it identifies the key factors that boards should address to promote a desirable ethical climate.
\end{abstract}

\section{Keywords}

Directors Duties, Duty Of Care, Ethical Climate

\section{Introduction: What do we Mean by a Duty of Care?}

When people accept an appointment as a director of a company they are legally bound by the requirements of the corporations law (Corporations Act 2001). These duties and responsibilities have gradually been extended and now apply to voluntary or appointed members of all incorporated organisations, government funded entities and a host of non-for-profit organisations incorporated under various Acts.

A Director has a greater duty than simply representing a particular field of experience.

Duties of Care and Diligence require a director to be:

- Familiar with the business of the organisation and how it is run.

- Sure that the board has sufficient means to audit the management of the company.

- Satisfied that the company is being properly run.

- Attend board meetings plus allow time to complete their responsibilities.

A Member of a Board must not make improper use of inside information to gain advantage for themselves, cause detriment to their organisation or engage in improper conduct which is inconsistent with the proper execution of their duties.

Furthermore Directors cannot place themselves in a position where their powers are restrained: ie where

Copyright (C) 2008 Victoria University. This document has been published as part of the Journal of Business Systems, Governance and Ethics in both online and print formats. Educational and non-profit institutions are granted a nonexclusive licence to utilise this document in whole or in part for personal or classroom use without fee, provided that correct attribution and citation are made and this copyright statement is reproduced. Any other usage is prohibited without the express permission of the their personal interests are in conflict with those of the organisation.

At first glance this appears fairly straight forward but it is not sufficient for a Director to rely solely on the company's officers or other persons. Think for example of the recent legislation which makes company directors responsible should a company be negligent in health and safety. The James Hardy case is a good 
example. The behaviour of management, subordinates and peers can also impinge on the duty of care of company directors. Taking or offering bribes are uppermost in our thinking.

Many such actions may not be illegal but they are unethical and often unethical attitudes and behaviours lead on to more serious fraud and other corrupt behaviour. Examples abound of company leaders setting an example that employees are too ready to follow. The managing director of Enron protested to the end of his trial that "he had done nothing wrong". Opes Prime is a good example of where greed in one organisation corrupted the morals of those with whom it had dealings. Opes Prime (Table 3) has been reported in newspapers as using client funds for its own purposes, lack of disclosure and transparency, conflicts of interest, etc

When a board fails to provide an ethical example to those dependent on them, and an ethical climate in which to work, these types of problems arise.

Throughout the world, corporate governance standards have proliferated in an effort to curtail these types of behaviour (Armstrong 2004b); (Standards Australia 2003a; Standards Australia 2003b; Standards Australia 2003c; Standards Australia 2003d; Armstrong and Francis 2004b; Armstrong and Francis 2004a; Standards Australia 2004) in its principles of good governance, states that a board should approve and foster an appropriate corporate culture matched to the entities values and strategies (Standards Australia 2003a, p.14). The ethical vales underlying the corporate governance standards are:

- Accountability

- Transparency

- Fairness and balance

- Honesty

- Dignity

- Legal compliance

- Good will

The type of climate promoted in an organization starts with the board. (Francis 2000; Australian Stock Exchange 2003, 2007; Standards Australia 2003b). The ASX in Principle 3 of its Good Corporate Governance guide states (p.25):

The company should clarify the standards of ethical behaviour required of the company directors and key executives (that is, officers and employees who have the opportunity to materially influence the integrity, strategy and operation of the business and its financial performance) and encourage the observance of those standards

\section{Ethical Climate}

Ethical climates are the stable, psychologically meaningful, shared perceptions that employees hold concerning ethical procedures and policies existing in their organisations. "Ethical climate is the perception of what constitutes right behaviour, and thus becomes a psychological mechanism through which ethical issues are managed" (Martin and Cullen 20006). Studies into ethical climate suggest that different climates may be related to various forms of individual behaviour and organisational performance.

Table 1: Theoretical dimensions of ethical climate

\begin{tabular}{|c|c|c|c|}
\hline \multirow{2}{*}{ Ethical Criteria } & \multicolumn{3}{|c|}{ Locus of analysis } \\
\hline & Individual & Local & Cosmopolitan \\
\hline Egoism & Self-interest & Company profit & Efficiency \\
\hline Teleological theory & Friendship & Team interest & Social Responsibility \\
\hline Deontological theory & Personal morality & $\begin{array}{l}\text { Company rules and } \\
\text { procedures }\end{array}$ & $\begin{array}{l}\text { Laws and professional } \\
\text { codes }\end{array}$ \\
\hline
\end{tabular}

Source: Victor and Cullen $(1987,1988)$ 
Based on a theoretical framework drawn from three ethical theories, Victor and Cullen $(1987,1988)$ using an Ethical Climate Questionnaire, found five types of climate (Table 2) that are called instrumental, caring, independence, rules, law and code.

Looking at the three ethical theories and relating these to the level of analysis (local or individual, company or society), a climate reflecting egoism, labeled instrumental, was characterized at the individual level by self interest and put instrumental values such as profits before anything else.

People operating in an instrumental climate may have good intentions, for example, the sustainability of a firm, but lack a moral basis for their reasoning. The model suggests that the locus of ethical reasoning shifts from individual, to company, to society at large. Goodpaster (quoted in van Hooft 2001) describes the single most serious threat to ethical decision making as teleopathy. The symptoms of this pathology are fixation, rationalisation and detachment. "Fixation' is the inability to let go of one's goals or to compromise them in any way. 'Rationalisation' is the willingness to justify one's activities in pursuit of one's goals with any plausible sounding reason. And 'detachment' is the inability to acknowledge or embrace the larger scheme of social and ethical values which ought to be expressed in one's decisions (Van Hoft 2001, p.92). This results in being too strongly wedded to one's goals. In business, the goals are likely to be exclusively profit and competitive advantage. Board decisions in such a climate would be based on serving the organisation's interests or providing personal benefits.

The second ethical climate type was caring. Those whose decisions were influenced by caring for the well-being of others, the teleologists, were influenced by friendship, identifying with the team and at a societal level, were supporters of social responsibility issues. Concern for and consideration of others is perceived to be supported by policies, practices and strategies of a firm, and by its actions. The final category of climates, associated with deontologists, were divided into three categories; independent, rules and law and code.. Individuals working in an independent climate believe that they should act on deeply held moral convictions. Decisions on ethical quandaries should have little regard for external forces and outside influences.

Table 2. Five common empirical derivatives of ethical climate

\begin{tabular}{l|ccc}
\hline Ethical Criteria & Individual & $\begin{array}{c}\text { Locus of analysis } \\
\text { Local }\end{array}$ & Cosmopolitan \\
\hline \multirow{2}{*}{ Egoism } & Instrumental & & \\
Teleological theory & \multicolumn{4}{|c}{ Caring } & & \\
\cline { 2 - 4 } Deontological theory & Independence & Rules & Laws and Codes \\
\hline
\end{tabular}

Source: Victor and Cullen $(1987,1988)$

In a rules climate, a company's rules and standards such as a code of conduct or governance principles are likely to set the climate. The law and codes climate will most likely suit professional people, whose activities are bound by laws and professional codes.

Our studies into ethical climate replicated aspects of the work of Victor and Cullen (1987, 1988); Wimbush and Shepard, (1994) Joseph and Deshpande (1997), and Deshpande (1996a, 1996b). In one study (Armstrong, Kasuma and Sweeney (1999) a survey of the 548 staff of a university in Victoria, Australia used a similar procedure to that used by Joseph and Deshpande (1997) and Deshpande (1996). In a second study, (Cockerell and Armstrong, 2000) our research explored the ethical climate in six gaming organisations.

Findings from our studies were similar to those found by previous researchers. The type of ethical climate was linked to various forms of organizational behaviours. Different organizations exhibited 
different ethical climates. Undesirable climates, reflecting an instrumental climate associated with egoism, were related to staff turnover, absenteeism, stealing, lying, falsifying reports and accepting gifts. Desirable ethical climates were related to various factors including the commitment to the organization, quality of working life and performance.

The conclusions from our studies were that an organization can influence behaviours in an organisation by promoting the ethical climate of an organisation. Consequently, the norms that guide a board's decisions about an organisation's policies, procedures, and practices have moral consequences. They provide both a reflection of the ethical climate supported by a board and a framework to guide employees' behaviour

\section{How do we Achieve an Ethical Board?}

Evidence of an ethical board would be:

- Compliance with its legal duties, in particular, those relating to due diligence and duty of care, and corporate governance standards affecting the performance of the board, audit committees and disclosure and transparency (See for example, Armstrong, 2004)

- A formal Code of Conduct.

- Regular reporting to the board on compliance with the Code.

- Procedures for detecting, recording and dealing with breaches of the Code and complaints;

- A training scheme for fostering of ethical conduct.

The first strategy is that a board should approve a written Code of Conduct:

The Code of Conduct should set out ethical and behavioural expectations for both directors and employees. It is critical that both the board and the senior management team demonstrate through both their words and actions, absolute commitment to that Code and consistency in its execution. (Standards Australia 2003, p. 16)

The Code should address such issues as conflicts of interest, improper use of company information, information security, insider trading, outside employment, gifts, entertainment and political contributions, confidentiality, and conducting business overseas. It should also include details of the consequences of non-compliance.

Ethical issues faced by a board also involve decisions about: employee issues such as fair wages, safe working conditions, work morale and industrial relations; consumer issues such as safety of products, honest advertising; and corporate responsibility demonstrated in relationships with suppliers and the community in which it operates, and its impact on the environment..

Sound data collection, not only statistics on corporate prosecution of white collar crime, but also about values and ethical climates across the corporate sector and within companies can support careful diagnosis of a situation and inform future action (Armstrong, 2003).

Ethics and the law have complementary roles. Ethics is about values and behaviour. There seems to be general agreement that regulation is not the answer to changing attitudes. However, it is possible to change behaviour by building capacity, training and getting data on the current climate to support the implementation of the right corporate culture.

Studies of the introduction of innovations (Ramage and Armstrong, 2005) show that both rational/technical and political/cultural factors are involved in a two stage process of adoption and operation of any innovation.

At board level, rational factors include the availability and commitment of resources, ethical skills, knowledge management techniques and externally-imposed requirements. A Board promoting an ethical climate would issue policy statements, develop a code of conduct and commit resources to data gathering In the adoption phase, the process is one of identifying the requirement for the changes and organising the organisation resources and skills, such as training, that may be required. During the 
adoption phase, board control and commitment, communication and sharing information become important.

Political/cultural factors to be addressed in the adoption phase are the influence of internal and external interest groups, conflicting priorities and the board members' concerns. Implementation requires leadership, addressing board attitudes to ethics and ethical decision-making, and identifying those who will be involved in the changes.

\section{Conclusion: Is Ethics Simply the Latest Fad?}

There has been a heightened interest in ethics because of the misconduct in and failure to control organisations such as Enron. HIH, AWC, OneTel, and the increased concern to shareholders and other stakeholders. In an increasingly global world, media exposure and public backlash to unacceptable behaviour are probable. Heightened visibility in a networked global world means "everyone knows about it" and comopanies are concerned for their reputations. Furthermore, research suggests that, 4 out of 5 employees (78\%) prefer a good workplace culture over a good salary (Commonwealth Bank Australia Newspoll Survey 2004)

Further support for promoting ethics on a Board is provided by Principle 3 of the ASX Principles of Good Governance and Best Practice (Australian Stock Exchange 2003, 2007) which include establilshing a code of conduct, and reporting and investigating unethical conduct. One can only conclude that the importance of personal and board member ethics is here to stay. This is not to say that introducing an ethical climate is an easy matter. As Transparency International (2004) reports:

a major constraint on the operationalisation of integrity systems is scepticism towards the integrity of senior management in many Australian organisations. This theme needs to be tackled through greater transparency relating to role expectations, remuneration, and material interests perceived as influencing corporate duties.

In the light of this, the corporate leaders of organisations, the board members, and their ethical stance demands further investigation.

\section{References}

Armstrong, A. (2003) Corporate governance: Can Governance Standards Change Corporate Behaviour? Australian Journal of Professional and Applied Ethics, 5 (2) pp.1-10.

Armstrong, A. (2004a). "Corporate governance standards: intangibles and their tangible value." Australian Journal of Corporate Law: 97-110.

Armstrong, A. and R. Francis (2004b). Applications of Corporate Governance. Sydney, Standards Australia International.

Armstrong, A. and R. Francis (2004). Introduction to Corporate Governance. Sydney, Standards Australia International.

Armstrong, A. Kusuma, H. and Sweeney, M. 1 (1999). The relationship between ethical climates and the quality of life. British Academy of Management Annual Conference. Manchester Metropolitan University, Manchester.

Australian Securities Exchange, (2003, 2007). "Principles of good Corporate Governance and Best Practice Recommendations." 2007, from www.asx.com.au/corporategovernance.

Cockerell, R. and A. Armstrong (2000). Ethical Climate and the Quality of Working Life. AICE99 Conference, . Swinburne University of Technology, Lilydale.

Despande, S. P. (1996a). "Ethical climate and the link between success and ethical behaviours: An empirical investigation of a non-profit organisation." Journal of Business Ethics 15: 315-320.

Despande, S. P. (1996b). "The impact of ethical climate on facets of job satisfaction of nurses: An empirical investigation." Journal of Business Ethics 15: 655-660

Francis, R. (2000). Ethics and Corporate Governance: an Australian Handbook. Sydney, University of New South Wales. 
International, Transparency. (2004). Chaos or Coherence: Strengths, Challenges and Opportunities for Australia's National Integrity Systems. Brisbane, Griffith University.

Martin, K. D. and J. B. Cullen (20006). "Continuities and Extensions of Ethical Climate Theory: A meta-analytic review." Journal of Business Ethics 69: 175-194.

Armstrong, A. (2004). "Corporate governance standards: intangibles and their tangible value." Australian Journal of Corporate Law: 97-110.

Armstrong, A. and R. Francis (2004). Applications of Corporate Governance. Sydney, Standards Australia International.

Armstrong, A. and R. Francis (2004). Introduction to Corporate Governance. Sydney, Standards Australia International.

Australian Stock Exchange, A. (2003, 2007). "Principles of good Corporate Governance and Best Practice Recommendations." 2007, from www.asx.com.au/corporategovernance.

Francis, R. (2000). Ethics and Corporate Governance: an Australian Handbook. Sydney, University of New South Wales.

Martin, K. D. and J. B. Cullen (20006). "Continuities and Extensions of Ethical Climate Theory: A meta-analytic review." Journal of Business Ethics 69: 175-194.

Ramage, P. . and Armstrong. A. . (2006). "Implementation: the next challenge in the use of performance measurement within Victoria's human services agencies." Evaluation Journal of Australasia 5(2): 5-17.

Smith, J., A. Armstrong, et al. (2007). "Professionalism and Ethics in Financial Planning." Journal of Business Systems Governance and Ethics 2(1): 1-10.

Standards Australia (2003a, b, c,d). Good Governance Principles. Australian Standard 8001-2003 Fraud and Corruption.8002-2003 Organizational Codes of Conduct. Sydney, Standards Australia: 1-12.Australian Standard AS 8003-2003 Corporate Social Responsibility. AS 8004 Whistleblower protection programs for entities. Sydney, Standarads Australia.

Transparency International (2004). Chaos or Coherence: Strengths, Challenges and Opportunities for Australia's National Integrity Systems. Brisbane, Griffith University.

United Nations, (2000). The Global Compact, United Nations.. ttp://www.unglobalcompact.org.

Van Hoft, S. (2001) Overcoming principles: dialogue in business ethics. Teaching Business Ethics, 5, pp. 89-106.

Victor, B. and Cullen, J.B. (1987) A theory and measure of ethical climate in an organisations. In W.C. Frederick (Eds), Research in Corporate Social Performance and Policy, JAI Press, Greenwich, pp.51-71.

Victor, B. and Cullen, J.B. (1988) The organisational bases of ethical work climate. Administrative Science Quarterly, 33, pp.101-125. 